\title{
Ten years older and no wiser
}

\author{
D.Henderson \\ Department of Chemistry and Biochemistry, \\ Brigham Young University, \\ Provo, Utah 84602, USA
}

Received April 15, 2005

In a moment of madness, I wrote a summary of my life for the volume of Molecular Physics [1] that noted my sixtieth anniversary. Evidently, I must have caused the editors of this issue some problems because in revenge they have requested that I write something summarizing the last decade. Obviously, I cannot write such an adventurous account as I did for Molecular Physics. Men in their sixties do not go to sea or go into a mine, unless, of course, this has been their career.

However, I can note one adventure. Rose-Marie and I went to Kenya on a safari followed by a trip to the Seychelles Islands. This is my second sightseeing trip to a game reserve in Africa (the other being in South Africa) and Rose-Marie's first. In Kenya we slept in a tent and saw lions dining. Their table manners are awful. When their meal is finished, they sleep wherever they want. Obviously, they have no predators, other than man. Other firsts for both of us were the sight of a leopard and a rhinoceros. I took a ride over the African plain in a hot air balloon. The Seychelles are beautiful and are one of two homes for giant sea turtles, the other being the Galapagos Islands.

Most importantly, our extended family has grown from three to eight grandchildren (two of whom were born just after my sixtieth birthday). Grandchildren are more delightful than children, if only because you can send them home when your patience wears thin. I am grateful for the support of Rose-Marie and for my children. All of us have survived our daughter's teenage years. We have seen them grow into such fine women.

As I reflect upon my career, I am increasingly aware of how fortunate I have been to have such good friends. They are friends who combined scientific excellence with outstandingly good characters. Marcelo Lozada y Cassou once commented he was amazed because ALL my friends were so likeable. Perhaps this is just good fortune but perhaps I am instinctively attracted to fine people and automatically reject the company of selfish people. Whatever the reason, I am grateful for their friendship.

I am reminded of a story that an uncle related to me. Around 1930, he joined a cavalry regiment in the British army. At that time, members of a cavalry regiment 
still rode horses. Their barracks were right above the stables and were permeated with distinctive odors. On Saturday they would clean themselves and put on civilian clothes that were located in a locker next to their bed and go to a local dance hall. The girls with whom they danced and had not met previously would immediately comment, "you're in the cavalry". A man is known by the company he keeps. So it is with me and I am grateful. My friends are important because for me science is a social as well as an intellectual pursuit. Undoubtedly, my success is due to my colleagues. I have no interest in working with someone unless he is smarter than I am. How else can I learn anything?

It is important for me to acknowledge the role of Henry Eyring and John Barker in my life. Both have moved to higher callings but were present in spirit at the conference. I am grateful to Sefton Hamann who did much to make possible the year that I spent in Australia with John Barker. Perhaps this is also an appropriate place to mention Malcolm Renfrew of the University of Idaho who was a helpful mentor when I started out.

I am grateful for Farid's remarks [2]. He has commented that one of his responsibilities was to keep management at bay. He was outstandingly successful at this and I am thankful. I recall once the laboratory director commenting on the number of Nobel Prizes that members of the Zurich laboratory had received and wondering what the Zurich laboratory management fed their staff members. Rather, I think that the Zurich laboratory management refrained from being back seat drivers. Great science is done by great scientists and not by great management, either through scientific or dietary guidance. Of course, management plays an important role in providing an encouranging environment. This role is important but not essential as anyone who has visited the laboratory of Pierre and Marie Curie knows. Farid and I are both old curmudgeons (scientific Andy Rooneys), as our wives will attest. What is worse, we are pleased to be curmudgeons. Despite this, we are something of an odd couple. I am genuinely fond of Farid and believe that he reciprocates. Farid has commented that I entertained him and John at lunch at IBM with stories of my life. At the time he said that he would write these stories down and publish them and make me famous with a 'Surely you are joking Mr. Henderson' book. Unfortunately, other things intervened. He did not do so and seems to have forgotten all but a few of the most amusing stories. My chance to be as famous as Feynman has been lost.

David Busath and Andrij Trokhymchuk organized the seventieth birthday festivities. The conference was Bob Eisenberg's idea and the festschrift was Andrij's idea. David was the chief organizer of the conference and he found Andrij and Morad Alwaneh to be helpful. Bob Eisenberg is the editor-in-chief of this festschrift but like all successful leaders he knows how to delegate. As a result, Andrij is the chief workhorse for the festschrift. I have published a few papers on the applications of statistical mechanics to physiology and without the guidance of David, Bob, and Wolfgang Nonner, another gentleman, these would have been the ravings of a madman. I have worked with Andrij (in the Ukraine, Mexico, and BYU) longer than anyone other than John Barker and Farid Abraham. This has been scientifically productive and it has been a great pleasure to be associated with him. Also, I am 
grateful to Myroslav Holovko and Orest Pizio not only for their friendship and scientific association but for introducing me to Andrij.

I am amazed at how successful, not only in science but in a broader way, my friends and coauthors have been. Bob Watts was Dean of Science at the University of Melbourne and then Chief (he claims only) Scientist at Broken Hill PTY, an Australian conglomerate. He is now retired. Bill Smith is Dean of Science at the Ontario Technical University. Luis Mier y Teran has been Dean of Science, Rector and General Rector at the Universidad Autonoma Metropolitana in Mexico. Marcelo Lozada and Gustavo Chapela are important Mexican Petroleum executives. Darsh Wasan is Vice-President of Illinois Institute of Technology and the editor of an important journal. Of course, he achieved this before we worked together. But at least I did him no harm. I am grateful to him because he helped me at an important stage of my career. The closest John Rowlinson and I came to collaborating was when he contributed a chapter to a book that I edited. John is now Sir John Rowlinson. I cannot help but wonder what might have happened if John and I had published something together. Lord Rowlinson?

Tony Haymet has been a special friend over the years. He is Chief of the CSIRO Division of Marine Science in Australia. Other long term friends that I can mention are Bill Hoover, Francis Ree, George Stell, Eckhard Spohr, Ron Fawcett, Jean-Pierre Badiali, and Ali Mansoori. I have published important papers with Lesser Blum, Kwong-yu Chan, Stefan Sokolowski and Bari Bhuiyan. They are good friends with whom I colloborate on and off. Younger colleagues whose collaboration I value are Dezso Boda, Monika Valisko, Dirk Gillespie, and Rick Gee.

I should make special mention of Masao Chen who has kept active in research even though he is employed by a two year college. Another Taiwanese who has a special place in my memory is Der-ming Duh, a very promising young theoretician who worked with me in Mexico and BYU for a period of a little more than a year. He changed careers and attended a Bible seminary. He is now a Pastor in southern Taiwan and, I am confident, is a source of inspiration and comfort to his flock. He says that I inspired him to make this change. I doubt it. I believe that he was leaning this way before he worked with me. At least, I did not detract from his inclination.

I am grateful to the BYU chemistry department and BYU more generally for taking me in at a late stage in my career. Randy Shirts, Earl Woolley, and Fran Nordmeyer did much to make this possible. I have benefited from working with Randy Shirts of the BYU chemistry department and James Lewis of the the BYU physics department. Richard Rowley and Dean Wheeler of the BYU chemical engineering department have been important colleagues.

Recently, a friend, Stewart Glazier, asked when I intended to retire ((perhaps if would be a better word than when). My reply was that I must grow up first. In any case, Bob Eisenberg says that he wants to organize something for my eightieth birthday. I cannot miss that.

Finally and most importantly, let thank Rose-Marie for 45 years of loyalty, support, and love. 


\section{References}

1. Henderson D. The misadventures of a NAFTA Scientist: physics and phun in Canada, the United States, and Mexico. Mol. Phys., 1995, 86, 551-565.

2. Abraham F. I am privileged to have co-authored with Doug, p. 241 of this issue. 